\title{
Assistance algorithm of nursing for amiodarone intravenous infusion
}

\author{
Algoritmo assistencial de enfermagem para infusão de amiodarona intravenosa
}

Algoritmo de atención de enfermería para infusión de amiodarona intravenosa

Francimar Tinoco de Oliveira ${ }^{1}$, Graciele Oroski Paes $^{1}$, Maria Gefé da Rosa Mesquita ${ }^{1}$, Victor Magalhães de Paula Souza $^{2}$, Elaine dos Santos Carlos ${ }^{3}$, Caroline Scantamburlo Martins ${ }^{1}$

This study aimed at identifying scientific publication on phlebitis caused by amiodarone and proposes a nursing care algorithm for interventions in intravenous amiodarone administration grounded in the Infusion Nursing Society and the Center for Disease Control and Prevention. It is a descriptive study mediated by integrative review in MedLine, LILACS, IBECS, BDENF, Cochrane Library and Scielo bases, published from 2006 to 2013 . The sample consisted of nine articles. The evidence pointed the incidence of phlebitis due to the infusion of amiodarone and the need to control this event. The algorithm proposed shows the materials to be used and the procedure of drug administration in order to minimize injury. Besides subsidizing the development of future studies, this algorithm also promotes the incorporation of the best recommendation for the interventionist clinical practice.

Descriptors: Phlebitis; Nursing Care; Education, Nursing; Amiodarone; Catheterization, Peripheral.

Objetivou-se identificar publicações científicas sobre flebite ocasionada por amiodarona e propor um algoritmo assistencial de enfermagem para intervenções na administração intravenosa de amiodarona, pautado na Infusion Nursing Society e no Center for Disease Control and Prevention. Estudo descritivo, mediado por revisão integrativa nas bases MEDLINE, LILACS, IBECS, BDENF, Biblioteca Cochrane e Scielo, publicados de 2006 a 2013. A amostra consistiu de nove artigos. As evidências apontaram a incidência de flebite decorrente da infusão de amiodarona e a necessidade do controle deste evento. 0 algoritmo proposto norteia os materiais a serem utilizados e o procedimento de administração do medicamento com vistas à minimização do agravo. Este algoritmo, além de subsidiar o desenvolvimento de estudos futuros, também propicia a incorporação das melhores recomendações para a prática clínica de forma intervencionista e legítima.

Descritores: Flebite; Cuidados de Enfermagem; Educação em Enfermagem; Amiodarona; Cateterismo Periférico.

Los objetivos fueron identificar publicaciones científicas sobre flebitis causado por amiodarona y proponer un algoritmo de atención de enfermería para intervenciones en la administración intravenosa de amiodarona, basada en la Infusion Nursing Society y Center for Disease Control and Prevention. Estudio descriptivo, llevado a cabo por revisión integradora en bases MedLine, LILACS, IBECS, BDENF, Biblioteca Cochrane y Scielo, publicados de 2006 a 2013. La muestra consistió de nueve artículos. Las evidencias señalaron incidencia de flebitis debido a la infusión de amiodarona y la necesidad de su control. El algoritmo propuesto nortea los materiales que deben ser utilizados y el procedimiento de administración del medicamento, objetivando minimizar agravios. Esto algoritmo, además de subsidiar el desarrollo de futuros estudios, también promueve la incorporación de mejores recomendaciones para la práctica clínica de forma intervencionista y legítima.

Descriptores: Flebitis; Atención de Enfermería; Educación en Enfermería; Amiodarona; Cateterismo Periférico.

\footnotetext{
${ }^{1}$ Universidade Federal do Rio de Janeiro. Rio de Janeiro, RJ, Brazil.

${ }^{2}$ Universidade do Estado do Rio de Janeiro. Rio de Janeiro, RJ, Brazil.

${ }^{3}$ Instituto Estadual de Cardiologia Aloísio de Castro. Rio de Janeiro, RJ, Brazil.

Corresponding author: Francimar Tinoco de Oliveira

Escola de Enfermagem Anna Nery, Departamento de Enfermagem Médico-Cirúrgica. Rua Afonso Cavalcanti, 275 - Cidade Nova, CEP: 20211110. Rio de Janeiro, RJ, Brazil. fran.toliveira@gmail.com
} 


\section{Introduction}

The intravenous therapy consists in administrating intravenous medication. Its venues is as varied as the type of the population in need of this practice specialization, ranging from the hospitalized newborn to the elderly in a health institution or at home ${ }^{(1)}$.

Around $90 \%$ of the hospitalized patients receive some kind of intravenous therapy and, for being related to an invasive procedure in order to obtain venous access whether peripheral or profound its use is not exempt of risks and complications, these are estimated in around $50 \%$ to $75 \%{ }^{(2)}$. Its complications are classified as local and systemic. The local ones can be recognized early through an objective evaluation. They are, as follows: hematomas, thrombosis, phlebitis (mechanical, chemical, bacterial or post-infusion), thrombophlebitis, extravasation, infiltration, local infection, venous spasm, misplaced catheter, ruptured catheter, and injury in the nerve, tendon or ligament. The systemic complications are: sepsis, circulatory overload, pulmonary edema, air embolism, and shock due to rapid infusion and embolism due to the catheter ${ }^{(1,3)}$.

Phlebitis is defined as an inflammation in the vessel in which the endothelial cells of the venous wall become inflamed and rough, due to chemical and infectious mechanical factors, thus allowing the adherence of platelets ${ }^{(4)}$. It is characterized by edema, pain, discomfort and erythema around the area of the insertion of the catheter or along the path of the vessel, and it is possible to have an evolution to a venous palpable cord. Usually the pain and the local edema can persist for several days or even weeks. These are influent factors to its development: inadequate technique of insertion of the catheter, clinical condition of the patient, characteristics of the vessel, incompatibility among the drugs, tonicity and too low or too high $\mathrm{pH}$ of the medicine or solution, ineffective filtration, caliber, size, length and material of the catheter, and prolonged time of insertion ${ }^{(1-2,5)}$.

The chemical phlebitis is directly related to the infusion of solutions or irritating and/or acid medication, inadequately diluted medication or to the mixture of incompatible medication, to fast infusion and the presence of small particles in the solution ${ }^{(1)}$.

Considering that the acceptable rate of phlebitis in a specific population of patients must be $5 \%$ or less, the measurement of its incidence is an important indicator of the rendered assistance ${ }^{(6)}$.

In helping the identification of phlebitis and having as objective to offer a standard of uniformity among the responsible health professionals for the intravenous therapy, the use of rating scales is recommended, so that there is higher diagnosis precision of that complication, thus avoiding sub notifications of those events. In this study the rating scale of phlebitis called Visual Infusion Phlebitis is used. This scale is divided into scores from 0 , indicating absence of symptoms of phlebitis, to 5 , with signals of purulent drainage, redness and palpable cord longer than $8 \mathrm{~cm}$, and for each one of its numeric classification, a specific action is recommended ${ }^{(7)}$.

In the intravenous therapy, the preservation of the venous net of the patients becomes indispensable. Therefore, the health professionals have a fundamental role in the prevention and reduction of the complications associated to the venous access ${ }^{(1)}$. The nurse is responsible for the intravenous therapy and for promoting the safety of the patient during its execution. But, it is noticed that in our assistance practice, its execution, from the installation of the venous catheter, its use for infusions and medication administration until its removal, has been made in a mechanistically way, and the characteristic of 'simple technique' is attributed to it, not considering specific continuous $\operatorname{care}^{(8)}$. A Brazilian study highlighted that the administration of medicine, independently of the way used, is a nursing intervention which requires dedication, specific technical knowledge and constant updating. However, in Brazil it has been performed as a simple task and attributed to the whole nursing team ${ }^{(9)}$.

Among the medicine with high risk of developing 
complications in intravenous therapy amiodarone is highlighted. It is an antiarrhythmic drug used in the treatment of ventricular and supraventricular arrhythmias, atrial fibrillation, atrial flutter and refractory ventricular tachycardia, and it is the most commonly used drug in atrial fibrillation, due to the amplitude of its electrophysiological properties and its systemic effects ${ }^{(10)}$. It is presented in $3 \mathrm{ml}$ ampules which contain $150 \mathrm{mg}$ of amiodarone hydrochloride and it has acid $\mathrm{pH}(\mathrm{pH}=4.08)$. The recommended dosage is approximately $5 \mathrm{mg} / \mathrm{kg} /$ body weight, the concentration of the solution for infusion IV ranges from 1 to $6 \mathrm{mg} / \mathrm{ml}$, however, concentration above 2 $\mathrm{mg} / \mathrm{ml}$ requires central venous access due to the high risk of phlebitis ${ }^{(4,11-12)}$. Therefore, its administration must be systematically assisted, in order to avoid complications associated to the therapy. According to the above mentioned, the problem researched was: How to reduce the occurrence of complications associated to intravenous therapy with amiodarone?

So, the objective was to identify the scientific production on phlebitis caused by amiodarone from 2006 to 2013 and to propose nursing algorithm assistance for interventions in intravenous amiodarone administration.

\section{Method}

In order to approach the scientific production on phlebitis caused by amiodarone the method of integrative revision of the literature was used, which enables the reunion and the synthesizing of the results of researches, of several methodological designs, on a specific theme or question favoring the enhancing of knowledge and its incorporation to the clinical practice $^{(13)}$.

The stages of its construction consisted in: elaboration of the question of research, stablishing the criteria of inclusion, defining the information to be extracted from the studies, search in the literature, highlighting the ones which make an association between phlebitis and the use of amiodarone, data collection, critical analysis of the studies included, discussion of the results and presentation of the integrative revision ${ }^{(13)}$.

The following question of research was defined: Which published studies in national and international scientific periodicals approached the occurrence, the care and the prevention of phlebitis caused by amiodarone infusion?

The following criteria of inclusion were used: a) articles published in national and international periodic which approached phlebitis caused by amiodarone; b) in Portuguese, English and Spanish; c) publishing from 2006 to 2013; d) full articles available on the data basis; e) clinical studies made in adults older than 18 years of age. Works without available abstracts and which presented duplicity were excluded.

The research was made in December, 2013. International resources were used as follows: LILACS, IBECS, BDENF, MEDLINE, Cochrane and Scielo.

In these data bases, advanced searches were made with the following Descriptors in Science of Health: infusion and phlebitis, intravenous infusion and phlebitis, peripheral venous catheters and phlebitis treatment and amiodarone and phlebitis.

120 articles were found, 41 of those in MEDLINE data basis, 06 in LILACS, 62 in Cochrane and 11 in Scielo. Using the methodology of search adopted in the IBECS and BDENF basis no study was found.

The application the criteria of inclusion and exclusion resulted in the exclusion of 108 articles $(33$ from MEDLINE, 05 from LILACS, 61 from Cochrane and 09 from Scielo), considering the theme of this revision and the duplicity of articles in the data basis. In a new evaluation, the reading and rereading of the full articles was performed, focusing the question of the research, nine articles were selected, eight of those were selected from MEDLINE and one from LILACS.

The selection was chronologically organized according to the publishing date. For the data collection and instrument elaborated in the Microsoft Excel 2007 software was used, which approached 
the identification of the article, the sample, the objectives, the methodology used, the methodological accuracy, measured interventions, results and main conclusions $^{(13)}$.

The methodological data of the studies selected were submitted to classification according to the levels of scientific evidence ${ }^{(14)}$ : level I, resulting from controlled study or from clinical guidelines based on systematic revisions of controlled randomized clinical trial; level II, well delineated randomized controlled clinical trial; level III, well delineated clinical trial without randomization; level IV, control study case or well delineated cut; level V, systematic revision of descriptive and qualitative studies; level VI, descriptive and qualitative studies; level VII, opinion of authorities and/or report of committees of specialists.
Afterwards the reading and analysis of study were made, allowing the elaboration of the guideline with recommendations concerning the theme.

\section{Results}

In the synoptic figure 1 , the studies found are present in a schematic way, in chronological order, associating the year, country, author, periodical, sample, design of the study and level of evidence.

All the studies selected ${ }^{(12,15-22)}$ relate the intravenous administration of amiodarone when performed peripherally to the occurrence of chemical phlebitis and thrombophlebitis.

\begin{tabular}{|c|c|c|c|c|c|c|}
\hline Year & Country & Authors & Periodical & Sample & Design & $\begin{array}{l}\text { Level of } \\
\text { evidence }\end{array}$ \\
\hline 2006 & Austria & $\begin{array}{c}\text { Hofmann R, Steinwender C, } \\
\text { Kammler J, Kypta A, } \\
\text { Leisch } F^{(15)}\end{array}$ & Int J Cardiol & 100 patients & Randomized & II \\
\hline 2006 & United Kingdom & $\begin{array}{c}\text { Showkathali R, Earley MJ, } \\
\text { Sporton } \mathrm{S}^{(16)}\end{array}$ & $\begin{array}{l}\text { Emerg } \\
\text { Med I }\end{array}$ & 1 patient & Case Study & IV \\
\hline 2007 & Greece & $\begin{array}{l}\text { Xanthos T, Bassiakou E, Vlachos } \\
\text { IS, Bassiakos S, Michalakis K, } \\
\text { Moutzouris DA et a (17) }\end{array}$ & Int J Cardiol & 223 patients & Randomized & II \\
\hline 2007 & $\begin{array}{c}\text { United States of } \\
\text { America }\end{array}$ & $\begin{array}{l}\text { Slim AM, Roth JE, Duffy B, Boyd } \\
\text { SY, Rubal BJ }]^{(18)}\end{array}$ & Mil Med & 273 patients & $\begin{array}{l}\text { Descriptive, } \\
\text { exploratory }\end{array}$ & III \\
\hline 2008 & Brazil & Martinho RFS, Rodrigues $\mathrm{AB}^{(12)}$ & Einstein & 40 patients & $\begin{array}{l}\text { Descriptive, } \\
\text { exploratory }\end{array}$ & III \\
\hline 2010 & Spain & $\begin{array}{c}\text { Ferrete-Morales C, Vázquez- } \\
\text { Pérez MA, Sánchez-Berna M, } \\
\text { Gilabert-Cerro I, Corzo-Delgado } \\
\text { JE, Pineda-Vergara JA, } \\
\text { et al }{ }^{(19)}\end{array}$ & Enferm Clin & $\begin{array}{c}3978 \\
\text { catheterizations }\end{array}$ & $\begin{array}{l}\text { Descriptive, } \\
\text { prospective }\end{array}$ & III \\
\hline 2011 & $\begin{array}{c}\text { United States of } \\
\text { America }\end{array}$ & Mowry JL, Hartman LS ${ }^{(20)}$ & $\begin{array}{l}\text { West J Nurs } \\
\text { Res }\end{array}$ & 2423 patients & $\begin{array}{l}\text { Observational, } \\
\text { before and after }\end{array}$ & III \\
\hline 2012 & $\begin{array}{c}\text { United States of } \\
\text { America }\end{array}$ & Boyce BA, Yee BH ${ }^{(21)}$ & $\begin{array}{l}\text { Crit Care } \\
\text { Nurse }\end{array}$ & 12 patients & $\begin{array}{l}\text { Descriptive, } \\
\text { exploratory }\end{array}$ & III \\
\hline 2013 & $\begin{array}{c}\text { United States of } \\
\text { America }\end{array}$ & $\begin{array}{c}\text { Norton L, Ottoboni LK, Varady } \\
\text { A, Yang-Lu CY, Becker N, Cotter } \\
\text { T, et } \mathrm{al}^{(22)}\end{array}$ & Am J Crit Care & 105 patients & $\begin{array}{l}\text { Descriptive, } \\
\text { retrospective }\end{array}$ & III \\
\hline
\end{tabular}

Figure 1 - Studies analyzed on the occurrence of chemical phlebitis caused by amiodarone 
One of them highlights that just the administration of the bolus of the amiodarone is able to increase the above mentioned complications ${ }^{(15)}$. It is a fact that requires specific knowledge on the concentration and dilution of that medication by the nurse, in order to have the criteria evaluation of the venous access, from the beginning of the therapy.

Two studies report the safety related to the administration of the drug, one evaluate high concentrations in only one bolus ${ }^{(15)}$ the second compares the effectiveness of its intravenous or oral administration $^{(17)}$, and both of them, despite focusing the matter of the treatment of the atrial fibrillation conclude that the observation of the episode of hypotension and phlebitis at the area of puncture must be reported and reaffirm the need of attention to the concentration of the drug.

The incidence of phlebitis was examined in a post-operative population which used the dosage, recommended by guidelines, $<2 \mathrm{mg} / \mathrm{ml}$, leading to the affirmation that the high rate of phlebitis observed is the most common complication in the infusion of that medicine, despite the recommended dosage ${ }^{(18)}$.

Another analysis ${ }^{(16)}$ is concerning a case study in the United Kingdom whose subject was a 79-yearold man treated at the emergency unit with $150 \mathrm{mg}$ of intravenous amiodarone through a catheter on a 20-gauge needle, in a vein of small caliber on the back of the left hand. After 72 hours of his original admission, he presented major thrombophlebitis. It is highlighted that, although thrombophlebitis is a well known complication of intravenous amiodarone, it is generally caused by high dosages (300-1200mg) or the prolonged administration in a peripheral vessel. The case study was based on a meta-analysis of 18 randomized clinical trials studying intravenous amiodarone in order to convert atrial fibrillation, whose results report a rate of $8 \%$ of phlebitis among 550 patients.

It is highlighted that even small dosages of venous infusion of amiodarone can cause thrombophlebitis, especially in vessels of small caliber and suggest the reconsideration of the caliber of the catheter and of the access ${ }^{(16)}$. These considerations lead us to cover a larger number of perspectives in the evaluation, prevention and treatment of phlebitis due to amiodarone, once only the control of its dilution could be sufficient to the control of the phlebitis.

Under the logic of assistance to the complications of the peripheral venous net caused by amiodarone, we present another selected study published in a Spanish nursing journal ${ }^{(19)}$. In it, the results of the implementation of a guideline of recommendations in handling peripheral venous catheter for five years are presented, with the aim of determining risk factors in the development of phlebitis in hospitalized patients. It is verified that after the implantation of the guidelines of recommendations, the incidence of phlebitis was decreasing and it confirms that the risks of phlebitis are high in the infusion in peripheral accesses of amiodarone and cefotaxime ${ }^{(19)}$.

As to the concentration of amiodarone solutions $^{(20-22)}$, tests with $900 \mathrm{mg} / \mathrm{ml}$ and $600 \mathrm{mg} / \mathrm{ml}$ were made in three distinct period ${ }^{(20)}$. In the first and third period, a solution of $900 \mathrm{mg} / \mathrm{ml}$ was used, and in the second period the least concentrated solution, and in this period it was evident the lower rates of phlebitis was evident. This result leads to a change of standardization of the solution of amiodarone in the institution $^{(20)}$.

The evaluation of phlebitis through the scale validated by the Infusion Nurses Society must be made, by a duly trained professional every four hours $^{(20-22)}$, as well as the recommendation of the use of a line filter of 0.22 micron and indication of central venous access in case the infusion of amiodarone remains longer than 24 hours $^{(20-22)}$.

In one of the selected publishing ${ }^{(22)}$ at first there was the retrospective evaluation of 18 months of the concentration of the solution of amiodarone, its administration, place and length of the therapy, and afterwards, the protocol of administration of this drug was refined by the teams of nurses, doctors and chemists. The following items were observed: the use 
of line filter of 0.22 micron; the recommendation of doses for peripheral and central venous accesses; the use of higher caliber vessels; the adjustment of the amiodarone for oral use, after 24 hours of intravenous administration; insertion of central venous catheter if the administration exceeds 24 hours; mandatory evaluation of the site of insertion of the venous catheter through the phlebitis scale and the register in an electronic medical record of the data ${ }^{(22)}$.

The only national study selected ${ }^{(12)}$ had the objective to identify the occurrence of phlebitis in patients who received amiodarone through peripheral venous access and describe which interventions of nursing were performed. Its conclusion reports that of the 40 patients which consisted the sample, $55 \%$ presented phlebitis. As intrinsic factors for the occurrence of such complication the age and condition of the vessels were identified and as extrinsic factors with dilution of the drug and absence of inadequate nursing actions. It should be noticed that although, in the institution under study, there is a guideline of recommendations which assists the exposed problems, the adherence of the nursing team was below the expected.

\section{Discussion}

Once the analysis of the articles is concluded, the scarcity of studies which showed the systematization of the infusion of the amiodarone was noticed. Updated information on the medicine therapeutics in the health institutions is absolutely necessary to be available, considering that, when the clinical practice is guided by managed recommendations, the reduction of complications becomes possible.

To stablish the opportunity of discussion on its application and promote constant orientation on the rates of complication can positively influence the team in their adhesion and in taking clinical decisions ${ }^{(23-24)}$.

\section{Elaboration of the algorithm}

Its elaboration foresaw the standardization not only of the technical execution and its structure, as well as the material which would be used. Recommendations as to the adequate handling of the system and on the evaluation of phlebitis were also described following the recommendations of the Infusion Nurses Society ${ }^{(6)}$ and of the Center for Disease Control and Prevention ${ }^{(25)}$, its flowchart is presented in figure 2 .

The materials to be used must comply with the following recommendations: catheter on needle of Vialon, caliber 20 Gauge (G); it has smooth surface of easy insertion, becoming soft and flexible after the installation; it floats inside the vein and does not allow the catheter to have contact with the intimate layer. It is indicated in prolonged therapies for reducing local reaction $^{(1,6)}$. The choice of the size of the catheter on needle is justified in the literature researched, where the use of vessels in catheters of wider caliber is indicated $^{(19,22)}$. It is presupposed that in conditions contrary to this indication the distribution and dilution of the medicine inside the vessel are slowed down, making a wider contact of the amiodarone with the venous endothelium possible, which increases the risks of inflammation of the same due to the $\mathrm{pH}$ of the $\operatorname{drug}^{(19,22)}$.

The flasks of glucose solution $5 \%$, and the sets of infusion and connectors must be constituted of polyethylene: because this is medicine which is sorbed in recipients and sets of polyvinyl chloride, this recommendation must be followed in order to avoid loss in the quantity of the medication to be administered $^{(6)}$.

Semipermeable transparent dressing: transparent and adhesive polyurethane pellicle. They are impermeable hypoallergenic and flexible dressings, to provide comfort for the patient once they mold them- 
selves to the skin. As they allow visualization of the site of the puncture, the early identification of complications related to the site of puncture is made easy. Its substitution is made in cases of compromising the integrity of the dressing, drainage through the site of insertion of the catheter at the moment of rotation of the site of peripheral venous puncture ${ }^{(6,25)}$.

Line filter of 0.22 micron: the line filter not only remove air and bacteria, but also small particles of drugs which were not adequately diluted ${ }^{(1,20-22)}$.
A study reports that in the administration of intravenous amiodarone without filters, even using the recommended dosage of $2 \mathrm{mg} / \mathrm{ml}$, the chances of phlebitis are 19 times higher of risk of basis ${ }^{(17)}$.

The Visual Infusion Phlebitis scale of evaluation $^{(7)}$, previously described, must be aggregated to the guideline of recommendations and to the flowchart of intervention presented in figure 2, having the objective to standardize the knowledge of the nursing professionals in maintenance and assistance of venous accesses.

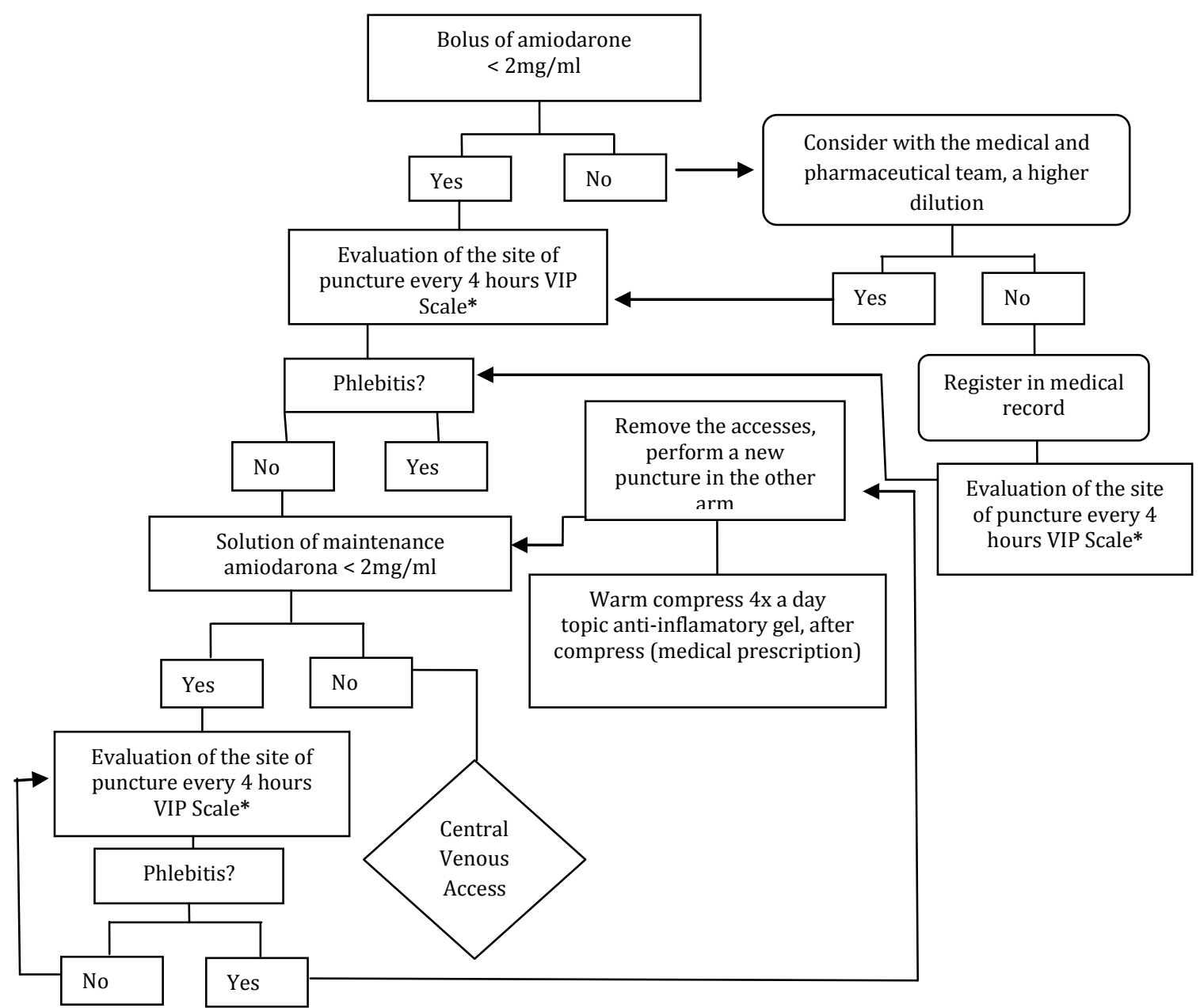

Figure 2 - Nursing assistance algorithm for the intravenous peripheral infusion of amiorarone

Incompatible drugs to infusion IV of amiodarone: Furosemide, Heparin sodium, Pantoprazole, Floxacilina, Quinidine, Aminophylline, Ampicillin, Argatroban, Bivalirudin, Cefamandole, Cefazolin, Ceftazidime, Digoxin, Imipenem, Magnesium Sulfate, Piperacillin, Piperacilina + Tazobactam, Potassium phosphate, Sodium Bicarbonate, Sodium phosphate. Visual Infusion Phlebitis ${ }^{(7)}-$ VIP* 
Description of the procedure: 1 . Proceed the peripheral venous puncture complying the guidelines stablished by Infusion Nurses Society and Center for Disease Control and Prevention, observing the caliber of the catheter on needle and the vessel to be accessed (avoid punctures in vessels of small caliber as in the back of the hand and forearm and catheters under $20 \mathrm{G})^{(6,16,22,25)} ; 2$. Use flasks of solutions and polyethylene set of infusion ${ }^{(6)}$; 3 . Use line filter of 0.22 micron between the catheter on needle and the set of infusion ${ }^{(1,17,20-22)} ; 4$. Register in a medical record the condition of the peripheral venous net, the number of attempts of puncture with and without success, which vessel was punctured, the caliber of the catheter on needle, the use of line filter, the time of the start of the infusion of the amiodarone ${ }^{(1)}$; 5. Perform the administration through infusion pumps $^{(11)} ; 6$. Check the concentration of the solution for intravenous infusion, concentrations above $2 \mathrm{mg} /$ $\mathrm{ml}$ require central venous accesses ${ }^{(11-12)} ; 7$. In case the patient is lucid and cooperative enough, inform him about the signals and symptoms of phlebitis and ask for the nursing team if necessary ${ }^{(21)}$; 8 . Evaluate the site of puncture after the infusion of the bolus, using the Visual Infusion Phlebitis scale ${ }^{(7)} ;$ 9. Evaluate the site of puncture during the infusion of the solution of maintenance using the Visual Infusion Phlebitis scale $^{(7)}$, every 4 hours; 10 . In case of evidence of phlebitis of any degree by the mentioned scale, remove the venous accesses performing the disinfection of the site of puncture and notify the medical team ${ }^{(7)}$; 11. Proceed with the new puncture preferably and if possible in the other arm, avoiding areas of flexion ${ }^{(6)}$; 12. Apply warm compresses for 20 minutes, three to four times a day ${ }^{(1,6)} ; 13$. Apply topic anti-inflammatory gel $^{(26)}$, after warm compresses (according to the medical prescription and after checking the historical report of allergy of the patient); 14. Register the occurrence of phlebitis and other adverse effects in the medical record as well as the adopted measures ${ }^{(6,20)}$; 15. Other common adverse effects of this therapy are bradycardia and hypotension, which must also be early notified in the medical record and with the notification to the medical team ${ }^{(1,6)} ; 16$. It is contraindicated to mix other preparations in the same syringe of preparation of the solution of amiodarone or use its line of infusion for other preparations ${ }^{(4,11)}$.

The information obtained in the studies highlighted the following elements:

1. Consider, together with the medical e pharmaceutical team, dilutions of the bolus of amiodarone in the assistance to the infusion with a concentration below $2 \mathrm{mg} / \mathrm{ml}: 300 \mathrm{mg}$ amiodarone $/ 200 \mathrm{ml}$ glucose solution $5 \%=1.5 \mathrm{mg} /$ $\mathrm{ml}$ or $300 \mathrm{mg}$ amiodarone/150 glucose solution $5 \%=2.0 \mathrm{mg} / \mathrm{ml}$ (its dilution must be made in glucose solution $5 \%$, once the information on the compatibility in preparations with physiological solution $0.9 \%$ is conflicting $\left.{ }^{(4,11-2)}\right)$;

2. Because the inflammatory process of the phlebitis is progressive, the catheter must be removed and a new access must be punctured, even in the cases of diagnosis degree 1 by the Visual Infusion Phlebitis scale ${ }^{(7)}$, in the following degrees the axillar temperature must be monitored, as well as the alterations in systemic inflammatory markers;

3. Consider together with the medical team the conduct of Venous Doppler in diagnosis degrees 3 and 4, for evaluation and documentation of thrombophlebitis;

4. Evaluate the number of substitutions of venous accesses every 24 hours, the extension of the areas of phlebitis and the need of maintenance of the intravenous amiodarone together with the multidisciplinary team, to consider the substitution of the catheter on needle by central catheter of peripheral insertion or in more complicated cases central venous catheters;

5. In the absence of transparent dressing, the standard dressing (gauze and adhesive bandage) must be changed daily for an adequate evaluation of the site of venous puncture ${ }^{(6,25)}$;

6. To promote the monthly evaluation of the indicator of quality rate of phlebitis of the Unit/ 
Institution through the recommended formula and stimulate the making of researches which can show the obtained results ${ }^{(27)}$ :

$$
\begin{aligned}
& \text { Incidence of Phlebitis }=\frac{\begin{array}{c}
\mathrm{n} \% \text { of cases of phlebitis } \\
\text { in the period }
\end{array}}{} \times 100 \\
& \mathrm{n} \circ \text { of patients - day with peripheral } \\
& \text { venous acess }
\end{aligned}
$$

\section{Conclusion}

Of the nine publishing selected in this revision, the greater part was classified as strong evidence, showing the incidence of phlebitis due to the intravenous infusion of amiodarone and the necessity of control of this event.

It is understood that a larger quantity of researches approaching this theme is necessary, for that, the elaboration of new studies is suggested so that they can measure the results of the recommendations displayed in the proposed algorithm and evaluate if their interventions decreased the incidence of phlebitis.

A limitation of this revision can be attributed to the period of years and the number of bases of data and virtual libraries chosen for the search made.

We hope to contribute for the updating of the knowledge on the theme presented; allowing the nursing professionals not only to follow their evolution, but, to improve the taking of clinical decisions and use measures of control and evaluation of the quality of the assistance rendered through the system of their indicators.

For that, we highlight the need of commitment of the responsible nurse for the direct care of the patient in this process, including the production of researches concerning the assistance practice..

\section{Collaborations}

Oliveira FT contributed for the conception and planning of the project, analysis and interpretation of the data, writing and elaboration of the article, critical intellectual revision of the data and final approval of the version to be published. Souza VMP, Carlos ES and Martins CS contributed for the analysis and interpretation of the data and writing of the article. Paes GO and Mesquita MGR contributed for the analysis and interpretation of the data, writing and elaboration of the article.

\section{References}

1. Phillips LD. Manual de terapia intravenosa. $2^{\mathrm{a}}$ ed. Porto Alegre: Artmed; 2001.

2. Ferreira LR, Pedreira MLG, Diccini S. Phlebitis among neurosurgical patients. Acta Paul Enferm. 2007; 20(1):30-6.

3. Silva LD, Oliveira FT. Recommendations for the use of saline solution $0,9 \%$ in peripheral venous catheters. Enferm Glob. [periódico na Internet] 2007 [citado 2011 Jan 6]; 6(11): [cerca de 9 p]. Disponível em: http://revistas.um.es/eglobal/ article/view/427/513.

4. Gilman AG, Godman LS, Rall TW, Murad F. As bases farmacológicas da terapêutica. 11aㅡ ed. Rio de Janeiro: McGraw-Hill Interamericana do Brasil; 2003.

5. Magerote NP, Lima MHM, Silva JB, Correia MDL, Secoli SR. Relation between phlebitis and peripheral intravenous catheter removal. Texto Contexto Enferm. 2011; 20(3):486-92.

6. Infusion Nurses Society. Infusion nursing standards of practice. J Infus Nurs. 2006. 29(1S):S58-S62.

7. Gallant P, Schultz AA. Evaluation of a visual infusion phlebitis scale for determining appropriate discontinuation of peripheral intravenous catheters. J Infus Nurs. 2006; 29(6):338-45.

8. Herdman TH. The nursing process: a time to remember its purpose. Rev Rene. 2013; 14(3):4589.

9. Camerini FG, Silva LD. Patient safety: analysing intravenous medication preparation in a sentinel network hospital in Brazil. Texto Contexto Enferm. 2011; 20(1):41-9. 
10. Sociedade Brasileira de Cardiologia. Diretrizes Brasileiras de Fibrilação Atrial. Arq Bras Cardiol [Internet] 2009 [citado 2013 Set 30]; 92(6 supl. 1): [cerca de 39 p]. Disponível em: http:// publicacoes.cardiol.br/consenso/2009/diretriz_ fa_92supl01.pdf

11. Trissel LA. Guia de bolso para fármacos injetáveis. Porto Alegre: Artmed; 2008.

12. Martinho RFS, Rodrigues AB. Occurrence of phlebitis in patients on intravenous amiodarone. Einstein. 2008; 6(4): 459-62.

13. Mendes KDS, Silveira RCCP, Galvão CM. Revisão integrativa: método de pesquisa para a incorporação de evidências na saúde e na enfermagem. Texto Contexto Enferm. 2008; 17(4):758-64.

14. Ursi ES, Gavão CM. Prevenção de lesões de pele no perioperatório: revisão integrativa da literatura. Rev Latino-Am Enfermagem 2006; 14(1):124-31.

15. Hofmann R, Steinwender C, Kammler J, Kypta A, Leisch F. Effects of a high dose intravenous bolus amiodarone in patients with atrial fibrillation and a rapid ventricular rate. Int J Cardiol. 2006; 110(1):27-32.

16. Showkathali R, Earley MJ, Sporton S. Amiodarone induced thrombophlebitis. Emerg Med J. 2006; 23(8):660.

17. Xanthos T, Bassiakou E, Vlachos IS, Bassiakos S, Michalakis K, Moutzouris DA et al. Intravenous and oral administration of amiodarone for the treatment of recent onset atrial fibrillation after digoxin administration. Int J Cardiol. 2007; 121(3):291-5.

18. Slim AM, Roth JE, Duffy B, Boyd SY, Rubal BJ. The incidence of phlebitis with intravenous amiodarone at guideline dose recommendations. Mil Med. 2007; 172(12):1279-83.
19. Ferrete-Morales C, Vázquez-Pérez MA, SánchezBerna M, Gilabert-Cerro I, Corzo-Delgado JE, Pineda-Vergara JA, et al. Incidence of phlebitis due to peripherally inserted venous catheters: impact of a catheter management protocol. Enferm Clin. 2010; 20(1):3-9.

20. Mowry JL, Hartman LS. Intravascular thrombophlebitis related to the peripheral infusion of amiodarone and vancomycin. West J Nurs Res. 2011; 33(3):457-71.

21. Boyce BA, Yee BH. Incidence and severity of phlebitis in patients receiving peripherally infused amiodarone. Crit Care Nurse. 2012; 32(4):27-34

22. Norton L, Ottoboni LK, Varady A, Yang-Lu CY, Becker N, Cotter T, et al. Phlebitis in amiodarone administration: incidence, contributing factors, and clinical implications. Am J Crit Care. 2013; 22(6):498-505.

23. Cassiani SHDB. Patient safety and the paradox in medication use. Rev Bras Enferm. 2005; 58(1):959.

24. Johansson ME, Pilhammar E, Khalaf A, Willman A. Registered nurses' adherence to clinical guidelines regarding peripheral venous catheters: a structured observational study. Worldviews Evid Based Nurs. 2008; 5(3):148-59.

25. Center for Disease Control and Prevention. Guidelines for the prevention of intravascular catheter -related Infections [Internet]. 2011 [cited 2011 Nov 20]; 1-83. Available from: http://www.cdc.gov/hicpac/pdf/guidelines/bsiguidelines-2011.pdf.

26. Cökmez A, Gür S, Genç H, Deniz S, Tarcan E. Effect of transdermal glyceryl trinitrate and antiinflammatory gel in infusion phlebitis. ANZ J Surg. 2003; 73(10):794-6.

27. Programa de Qualidade Hospitalar (CQH). Manual de Indicadores de Enfermagem NAGEH. São Paulo: APM/CREMESP; 2006. 